\title{
Performance measurement of the upgraded Microcab-H4 with academic drive cycle
}

\author{
Luthfi Rais*, Peter Fisher, Aman Dhir, Robert Steinberger-Wilckens \\ Chemical Engineering Department, University of Birmingham, Edgbaston, Birmingham B15 2TT, UK
}

Article history:

Received: 29 April 2016 / Received in revised form: 10 May 2016 / Accepted: 22 May 2016

\begin{abstract}
The original Microcab-H4, a hybrid fuel cell car, was tested with Academic drive cycle. After several years, the car was upgraded and tested with the ECE 15 drive cycle. The result showed the car has higher energy efficiency. However, the result could not be compared to the original car due to different drive cycle test. This research was done to measure the performance and energy efficiency of the Upgraded Microcab-H4 with Academic drive cycle. The measure of car energy efficiency was done through four tests: Run on battery, run on battery and Ballard fuel cell, and run on battery, Ballard, and Horizon fuel cell. The energy efficiency was calculated based on the hydrogen consumption after 5 cycles. The lowest energy efficiency was run on battery and Ballard fuel cell with $(1.01 \mathrm{~km} / \mathrm{MJ})$. The highest energy efficiency was run on battery, Ballard, and Horizon fuel cells $(1.10 \mathrm{~km} / \mathrm{MJ})$, which is higher than previous tests.
\end{abstract}

Keywords: drive cycle; energy efficiency; hybrid vehicle; hydrogen fuel cell; Microcab-H4

\section{Introduction}

In 2008, Five Fuel Cell Hybrid Vehicles of the type Microcab-H4 were built in Coventry, UK, by a consortium of Microcab Industry, RDM Automotive, and Delta Motorsport. These cars were used for a demonstrator project at the University of Birmingham [1]. At the same time, the first hydrogen fuelling station in the UK was built by Air Product at the University of Birmingham. This station can supply compressed hydrogen at 350 bar.

The hydrogen from the car tank was transferred to a Ballard fuel cell through a 10 bar gas regulator to produce electricity at $26 \mathrm{~V}$ at rated power. The fuel cell was arranged in parallel to the $1.5 \mathrm{kWh}(48 \mathrm{~V})$ lead acid batteries and A GE separately Excited DC electric motor $2.24 \mathrm{~kW}$ thus it could provide the power to both at the same time. A $12 \mathrm{~V}$ lead acid battery was used for starting system and auxiliaries. To charge the $12 \mathrm{~V}$ and $48 \mathrm{~V}$ batteries from the $26 \mathrm{~V}$ fuel cell, DC-DC converters were used [2].

Kendall et al [3] measured the performance of the Microcab-H4 with academic drive cycle at University of Birmingham. The result of energy efficiency was $0.71 \mathrm{~km} / \mathrm{MJ}$. Acceleration and battery charging system of the car were found to be the problems of the car. When the car stopped, the fuel cell power was not sufficient to charge the batteries and caused the batteries' depletion. The batteries also could not absorb the large pulse of breaking energy.

As response to the weakness of the Microcab-H4, Shang [2] redesigned the car to improve the performance and

* Corresponding author. Tel.: +62 85781008201

Email: rais.luthfi@gmail.com efficiency. In the new design, the $48 \mathrm{~V}$ lead acid batteries were replaced by $9.8 \mathrm{kWh}(54 \mathrm{~V})$ lithium ion phosphate $\left(\mathrm{LiFePO}_{4}\right)$ batteries that have higher energy density. To reach sufficient acceleration, a $3 \mathrm{~kW}$ Horizon PEM fuel cell was added. The $1.2 \mathrm{~kW}$ Ballard fuel cell was used as the energy supply for the auxiliaries and supports the Horizon fuel cell to power the motor. Shang [2] did not use DC-DC converters from Horizon fuel cell to the batteries because they contributed to the energy losses around $20 \%$ from fuel cell to the batteries. The motor was replaced with an Agni Lynch Pancake shape lightweight permanent magnet DC motor $(9.5 \mathrm{~kW})$ that has higher efficiency. Most of the components were set at 48V DC in order to eliminate energy losses. The car was tested with the ECE15 duty cycle at Shakespeare Country Raceway.

The vehicle could reach the acceleration of the duty cycle. The average energy efficiency of the new system was 0.98 $\mathrm{MJ} / \mathrm{km}$ (99.7mpg). This efficiency was almost 1.5 more efficient than the original car that was tested with the academic drive cycle. However, the result could not be compared to the test results of the original design of the Microcab-H4. This was because the drive cycle for the test of new design was different from the test of original design. The different drive cycle would result in different energy efficiency. Moore et al [4] showed that the car with the US06 drive cycle test produced lower energy efficiency than HIWAT, FUDS, and ECE drive cycle, which were less aggressive than US06.

Based on the problem of differences in drive cycle, this research was done to test the new design of Microcab-H4 or upgraded Microcab-H4 with the academic drive cycle that was the same as the test for the original car. With the same 
drive cycle, the comparison of energy efficiency between original and new car design could be obtained with more accuracy.

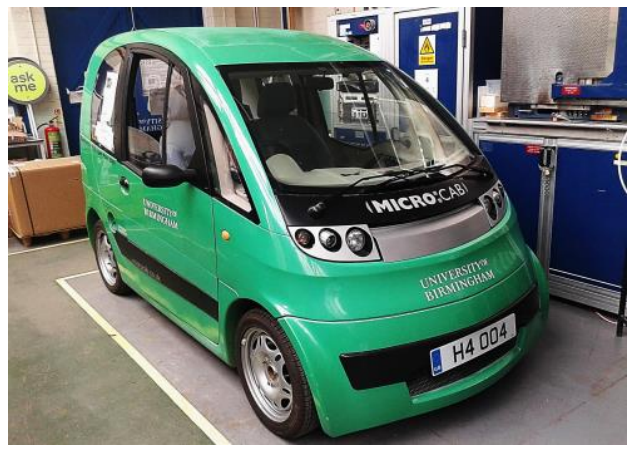

Fig. 1. Microcab-H4 that was used in this research

Run on only battery, run on battery and Ballard fuel cell, and run on battery, Ballard, and Horizon fuel cell with and without passenger were also done to measure the performance of $\mathrm{LiFePO}_{4}$ batteries, Ballard, and Horizon fuel cell in the car. The amount of hydrogen consumption and mileage for those four tests was measured to get energy efficiency. After that, the energy efficiency of this research was compared to the energy efficiency of the original car and upgraded car that was tested with ECE 15 drive cycle.

\section{Materials and Methods}

\subsection{Car Components and Configuration}

Microcab H-4 that was modified by Shang [2] was used for this research (Fig.1). The configuration of the car is shown in Fig. 2. The main components of the car are batteries, fuel cells, motor, and hydrogen tank. There are two kinds of battery in the car: a $12 \mathrm{~V}$ lead acid battery from Lucas that used as a power source for auxiliaries and 16 units of $3.4 \mathrm{~V}$ lithium iron phosphate $\left(\mathrm{LiFePO}_{4}\right)$ batteries from CALB that used as a power source for the motor. Those batteries were connected in series to produce $54.4 \mathrm{~V}$. This car has two fuel cells. The first fuel cell is $1.2 \mathrm{~kW}$ fuel cell from Ballard $\mathrm{Nexa}^{\mathrm{TM}}$ that is used to charge $12 \mathrm{~V}$ lead acid battery and support the $54 \mathrm{~V} \mathrm{LiFePO}_{4}$ battery when the motor need high power. The second fuel cell is $3 \mathrm{~kW}$ fuel cell from Horizon that is used to power the motor and charge $54 \mathrm{~V} \mathrm{LiFePO}_{4}$ battery. The specification of the both fuel cells is shown in Table 1.

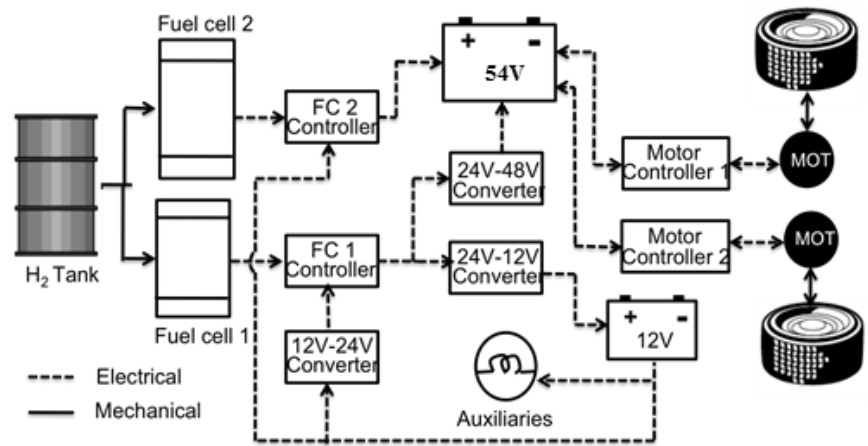

Two Agni Lynch Pancake shape DC motor (9.5 kW) type 95-R was used as the motor for a dual motor system of this car. To drive the wheels, belt and pulley mechanism were used. PM48501B motor controllers were installed to control and synchronize between the two motors. These motor controllers were also functioned for regenerative braking.

Table 1. Technical specification of fuel cells $[5,6,7]$

\begin{tabular}{llll}
\hline \multicolumn{1}{c}{ Specification } & Ballard FC & Horizon FC & \multicolumn{1}{c}{ LiFePO $_{4}$ battery } \\
\hline Number of Cell & 47 & 72 & 16 \\
Nominal & 1200Watt & $3000 \mathrm{Watt}$ & $3.4 \mathrm{~V}, 180 \mathrm{Ah} /$ cell \\
& $24 \mathrm{~V}$ & $43.2 \mathrm{~V}$ & $54.4 \mathrm{~V}, 180 \mathrm{Ah} / \mathrm{bank}$ \\
& & & $\leq 0.6 \mathrm{~m} \Omega$ \\
& & & - \\
Fuel Pressure & $0.7-17 \mathrm{bar}$ & $0.45-0.55 \mathrm{bar}$ & - \\
$\begin{array}{l}\text { Dimension } \\
\text { (L x W x H cm) }\end{array}$ & $56 \times 25 \times 33$ & $51 \times 16 \times 35.5$ & $18.2 \times 7.1 \times 27.5$ \\
Fuel & & & $($ per cell $)$ \\
consumption & $18.5 \mathrm{SLPM}$ & $39 \mathrm{~L} / \mathrm{min}$ & - \\
$\begin{array}{l}\text { Ambient } \\
\text { temperature }\end{array}$ & $3-40^{\circ} \mathrm{C}$ & $5-30^{\circ} \mathrm{C}$ & $(-20)-55^{\circ} \mathrm{C}$ \\
\hline
\end{tabular}

\subsection{Hydrogen Source}

The hydrogen gas for Microcab-H4 was from a hydrogen fuelling station that was built by Air Product at the University of Birmingham. The purity of hydrogen gas from that station is $99.99 \%$. In the car, the hydrogen was stored in a $0.025 \mathrm{~m}^{3}$ Dynecell tank with maximum pressure at 350 bar.

\subsection{Data Collection}

The Squirrel 2010 data logger was used to get the current and voltage data across fuel cells, batteries, and motor controllers. This logger was connected to the clamp sensors that were located on the batteries, fuel cells, and motor controller cable. DL1 GPS data logger from Race Technology was used to obtain the distance travelled $(\mathrm{km})$ and speed (mph) data. Temperature of the hydrogen tank was measured with laser thermometer and pressure with pressure gauge on the tank. The open circuit voltage of the batteries was measured by multimeter.

\subsection{Drive Cycle}

Academic drive cycle was used to test the car. The test was started and finished in the front of the Fuel Cell Laboratory, University of Birmingham. The total distance for the 1 cycle is $1.7 \mathrm{~km}$ or 1.06 miles. The speed of the car had to be maintained at $15 \mathrm{mph}$. The car was at low speed at the junction and when made a U-turn. The track of the academic drive cycle is shown in Fig.3. 


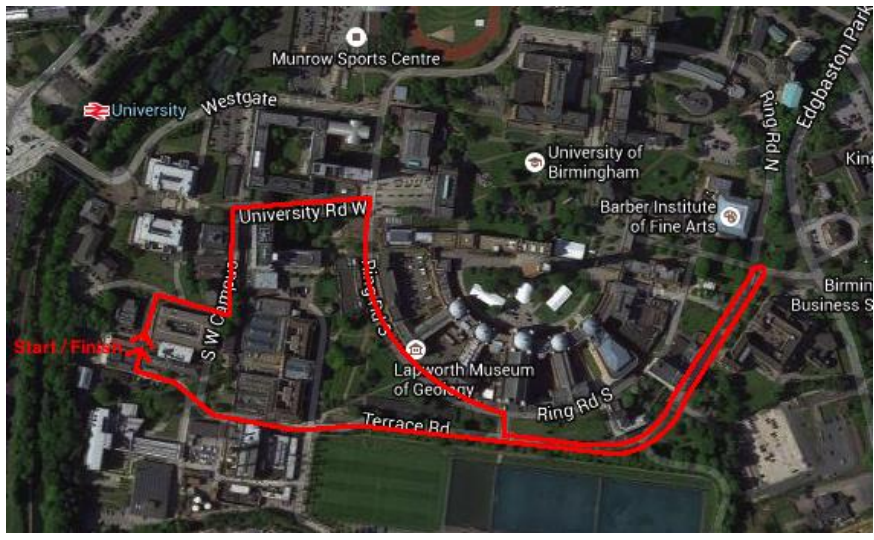

Fig. 3. Academic drive cycle

\subsection{Test Run}

There are four experiments for this research: Running the car powered by battery only (both fuel cells were turned off during running), powered by battery and Ballard fuel cell (Horizon fuel cell was turned off during running), powered by battery, Ballard and Horizon fuel cells with and without passenger. Running the car powered by battery and Horizon fuel cell was not done because it needs complex rearranging and reprogramming. Horizon FC cannot be turned on if Ballard fuel cell off [2]. Before the test, all the batteries must be fully charged. The car ran for 5 cycles of each test and every after 1 cycle, the car must be rested to charge the batteries with both fuel cells until the battery voltage same as start voltage. The hydrogen consumption for each running power system after charging time was calculated to get energy efficiency data.

Beside energy efficiency, the test run also was used to know the performance of $\mathrm{LiFePO}_{4}$ batteries, Ballard, and Horizon fuel cell in the car. The performance is based on the data from GPS and Squirrel logger.

\subsection{Energy Consumption Calculation}

The hydrogen consumption for 1 cycle is the difference between hydrogen mass in the tank before and after running (after charging) the car for 1 cycle. Eq. 1 from Zheng et al [8] was used to calculate the hydrogen mass in the tank.

$$
\mathrm{m}=\frac{\mathrm{pV}}{\mathrm{R}_{\mathrm{g}} \mathrm{T}(1+\alpha \mathrm{p} / \mathrm{T})}
$$

Where $\mathrm{m}$ is the hydrogen mass in the tank, $\mathrm{p}$ is the pressure absolute in the tank $\left(\mathrm{P}_{\text {atmosphere }}+\mathrm{P}_{\text {gauge, }}, \mathrm{MPa}\right), \mathrm{V}$ is the tank volume, $\mathrm{R}_{\mathrm{g}}$ is the hydrogen gas constant $(4124.3 \mathrm{~J} /(\mathrm{kg} \mathrm{K})), \alpha$ is a coefficient $\left(1.9155 \times 10^{-6} \mathrm{~K} / \mathrm{Pa}\right)$, and $\mathrm{T}$ is the temperature of the tank $(\mathrm{K})$. Equation 2 was used to calculate energy consumption.

$$
\mathrm{E}=\mathrm{m}_{\mathrm{H} 2} \mathrm{x} \mathrm{u}
$$

Where $\mathrm{E}$ is the energy consumption $(\mathrm{MJ}), \mathrm{m}_{\mathrm{H} 2}$ is the hydrogen consumption $(\mathrm{kg})$, and $\mathrm{u}$ is the energy density of hydrogen gas for low heating value $(120.21 \mathrm{MJ} / \mathrm{kg})$.

\section{Results and Discussion}

The results of the graphs show two cycles in order to obtain more detail of the data. The summary of all tests run is shown in Table 2.

\subsection{Run on Battery}

The result of GPS and battery condition for two cycle of run on battery is shown in Fig. 4. The speed was maintained around $15 \mathrm{mph}$ when there were no obstacles. The drop speed in the middle happened when the car made a U-turn. The car took around 5 minutes for 1 cycle. The distance travelled was about $1.7 \mathrm{~km}$ for one cycle. The green line show (Fig. 4(a)) that battery State of Charge little bit decreased during running and increased again until same as the start after the battery was charged. State of Charge (SOC) is the ratio of battery capacity at one time to the nominal capacity of the battery. The nominal capacity is the maximum capacity of the battery to store the charge [9]. The maximum capacity of the battery (SOC $=100 \%)$ is 180Ah [2]. The state of charge before run was $94.217 \%$, thus the capacity of battery at start was 169.591Ah. For the 1 cycle, based on Table 2, for current out from battery, it took around 3.533Ah. Because of the big difference between current out from the battery and the capacity of the battery, thus the decline of SOC during running was very slight.

When the car started to run, the current out from the battery was high and the battery voltage dropped (Fig. 4(b)). This is because to move the car from the idle position, it needed high torque from motor to overcome the static friction between roads and wheels [10]. To accelerate the car to higher speed, the motor needed higher current. However, to maintain the car at high speed, the motor need lower current because the momentum of the car helped it.

Table 2. Summary of four experiment for five cycles

\begin{tabular}{lccccccc}
\hline \multicolumn{1}{c}{ Run type } & $\begin{array}{c}\text { No of } \\
\text { cycle }\end{array}$ & $\begin{array}{c}\text { Distance } \\
\text { travelled (Km) }\end{array}$ & SOC Change & $\begin{array}{c}\text { Current to } \\
\text { battery } \\
(\mathrm{Ah})\end{array}$ & $\begin{array}{c}\text { Current out } \\
\text { from battery } \\
(\mathrm{Ah})\end{array}$ & $\begin{array}{c}\text { Battery power losses } \\
\text { (Wh) }\end{array}$ & $\begin{array}{c}\text { Wire power losses } \\
(\text { Wh) }\end{array}$ \\
\hline Battery & 5 & 8.455 & -0.502 & 17.666 & 11.452 & 27.604 & 4.094 \\
Battery and Ballard FC & 5 & 8.455 & -0.032 & 19.475 & 11.295 & 27.975 & 2.601 \\
$\begin{array}{l}\text { Battery, Ballard \& } \\
\text { Horizon FC }\end{array}$ & 5 & 8.455 & 4.001 & 19.099 & 11.083 & 7.145 & 4.224 \\
With passenger & 5 & 8.455 & 3.152 & 21.884 & 12.517 & 10.179 & 5.872 \\
\hline
\end{tabular}



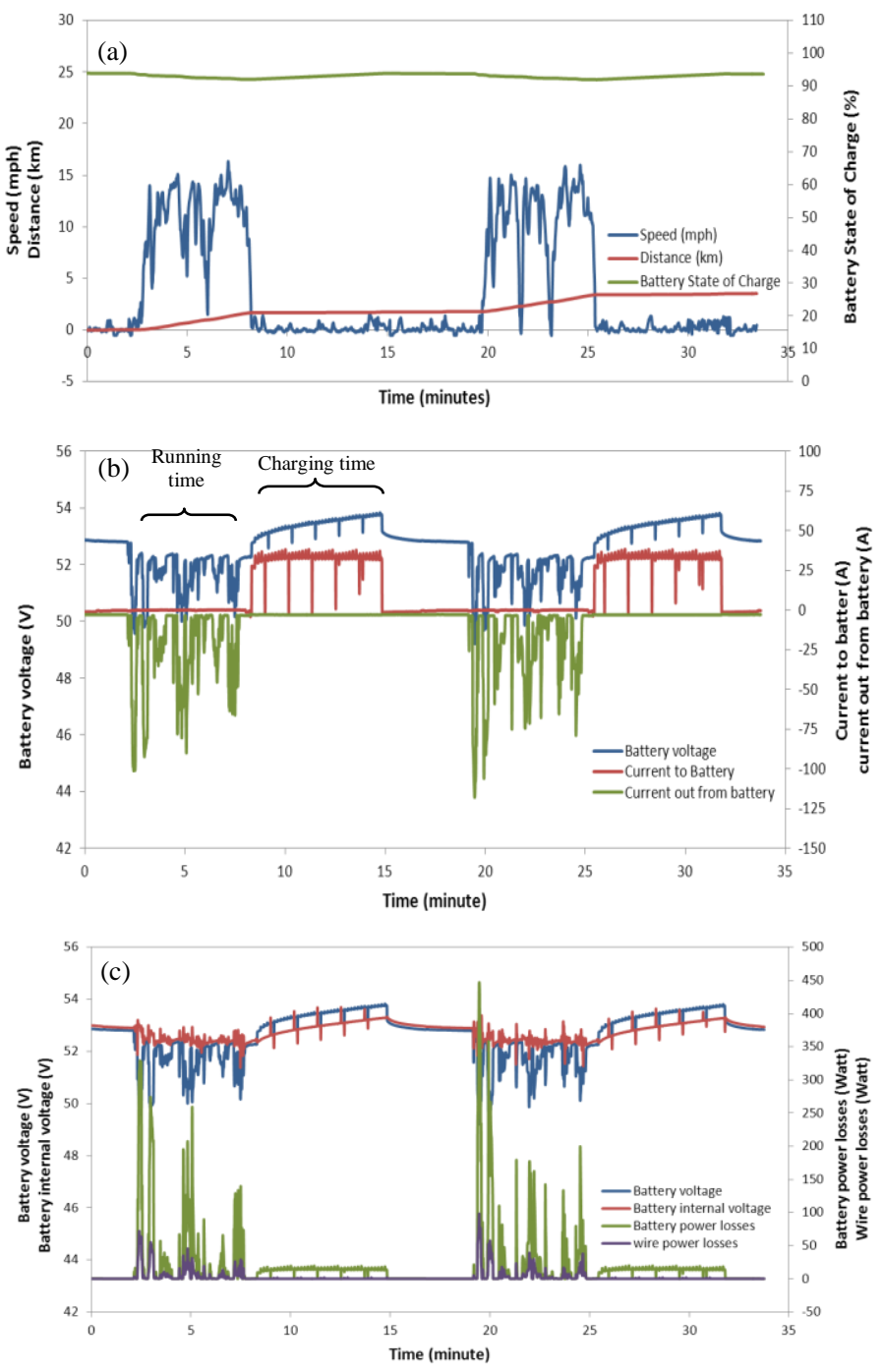

Fig. 4. (a) GPS result and battery state of charge (SOC); (b) battery condition; and (c) losses and battery internal voltage for run on battery

When the battery was first put on charge, the voltage shot up quickly. This is because the current from fuel cells flowed to the battery, thus the voltage that was measured was the battery voltage with the addition from fuel cells. After that, the voltage increased linearly. At the end, when the fuel cells were turned off, the battery voltage dropped down quickly. This dropped is because the fuel cells did not give the current to the battery anymore, thus the measurement was purely from the battery. After that, the battery voltage still decreased but not significantly. This is because the distribution of the current through the battery was non-uniform. All current from fuel cells flowed into the positive tab. Because of the resistance, the charge near the positive tab was higher than near the negative tab [11]. When the fuel cells were turned off, the charge needed time to be distributed uniformly.

After several minutes, the battery voltage was stable and this voltage was same as the voltage before the run. The distribution of charge in the battery during charging is shown in Fig. 5, where the red area is near the positive tab and the blue area is near the negative tab. During charging, there were some spikes from the battery voltage and current to the battery. These spikes came from the short circuit unit (SCU) at Horizon fuel cell. The SCU gave the load to the fuel cells to keep the good condition of the fuel cell for long-term performance [4].

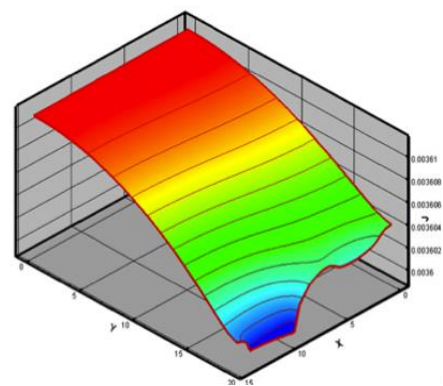

Fig. 5. The distribution of charge in the battery during charging process [11]

The battery power loss, which is shown by the green line in Fig. 4(c), was caused by internal impedance of the battery. This internal impedance of $\mathrm{LiFePO}_{4}$ battery consists of Solution Resistance (Rs), Charge Transfer Resistance (Rct), Constant Phase Angle Element (CPE), and Warburg Impedance (Wz) [12]. These losses happened when the battery was charged and discharged. The impedance in the form of circuit is shown in Fig. 6. The internal impedance of the battery based from the manufacturer is $\leq 0.6 \mathrm{~m} \Omega$ for each battery [7]

The resistance of the cable caused the wire losses, which are shown by the purple line in Fig. 4(c). The resistance of the cable depends on the diameter, length, and the material. Because of internal impedance, the battery internal voltage was different from the battery voltage that was measured by Squirrel logger. Battery internal voltage is the battery voltage minus voltage drop. The voltage drop was calculated with Equation 3.

$$
\mathrm{V}=\mathrm{Ir}
$$

Where $\mathrm{V}$ is the voltage drop, $\mathrm{I}$ is the current into the battery and $r$ is the internal impedance of the battery. The internal battery voltage shows the real battery voltage. With this voltage, it could show the decreasing trend line of the voltage during running which could be identified from the battery voltage (the red line and the blue line in Fig. 4(c)).

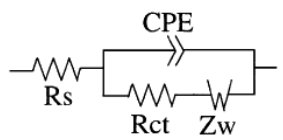

Fig. 6. Internal impedance circuit of $\mathrm{LiFePO}_{4}$ Battery [12]

\subsection{Run on Battery and Ballard Fuel Cell}

The result is shown in Fig. 7(a)-(c). In Fig. 7(b), there were some spikes from current to the battery (the red line) which was not appear for run on battery. These spikes were from Ballard fuel cell. Shang [2] set the Ballard fuel cell to supply the power continuously to $12 \mathrm{~V}$ lead acid battery for auxiliaries via 24-12V DC-DC converter. This Ballard fuel cell could not supply the power continuously to the $54 \mathrm{~V} \mathrm{LiFePO}_{4}$ battery because it had to be supplied via $24-48 \mathrm{~V}$ DC-DC converter. The output of this DC-DC converter was $50 \mathrm{~V}$. Therefore, the Ballard fuel cell could only supply 

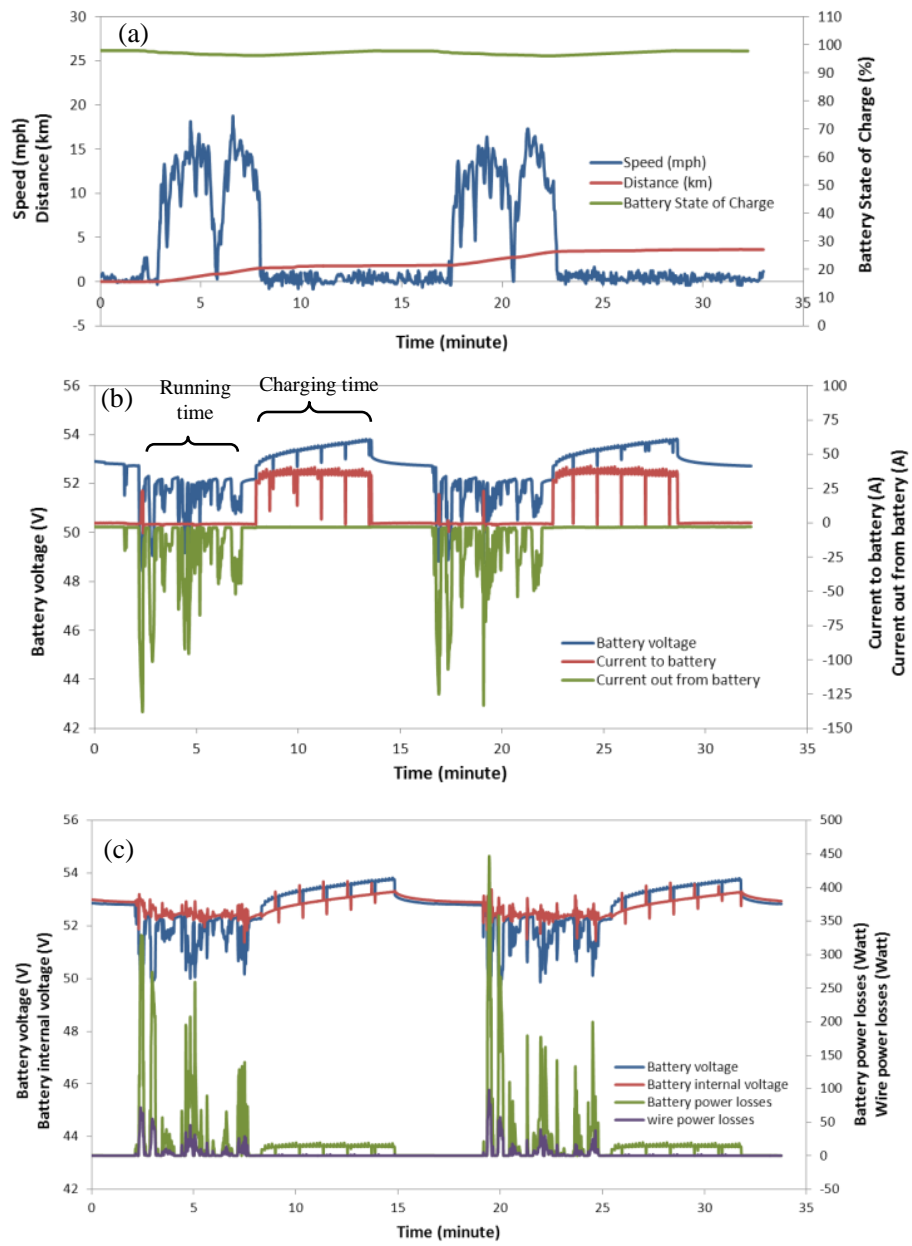

Fig. 7. (a) GPS result and battery state of charge (SOC); (b) battery condition; and (c) Losses and battery internal voltage for run on battery and Ballard fuel cell

the power to the $\mathrm{LiFePO}_{4}$ battery if the battery voltage was lower than $50 \mathrm{~V}$. In this experiment, the battery voltage was lower than $50 \mathrm{~V}$ when the motor needed high power hence the Ballard just supplied the power to the $\mathrm{LiFePO}_{4}$ battery when needed high power. However, this depends on the start voltage.

There were just a few of peaks during running. That means the Ballard just supply the small amount of power to the $\mathrm{LiFePO}_{4}$ battery during running. Therefore, there were no significant differences for charging time and power losses compared to run on battery. The losses during running and charging are shown in Fig. 7(c).

\subsection{Run on Battery, Ballard, and Horizon Fuel Cell without Passenger}

The result is shown in Fig. 8(a)-(c). In this experiment, the battery state of charge was stable during the test run (Green line in Fig. 8(b)). This is because the fuel cell continuously charged the battery during running time and charging time. Because the battery state of charge was stable, the average charging time after 1 cycle just took short time that was 0.4 minutes. The current to battery was not constant during running. That means the fuel cell supply the current depend on the current required by the motor.
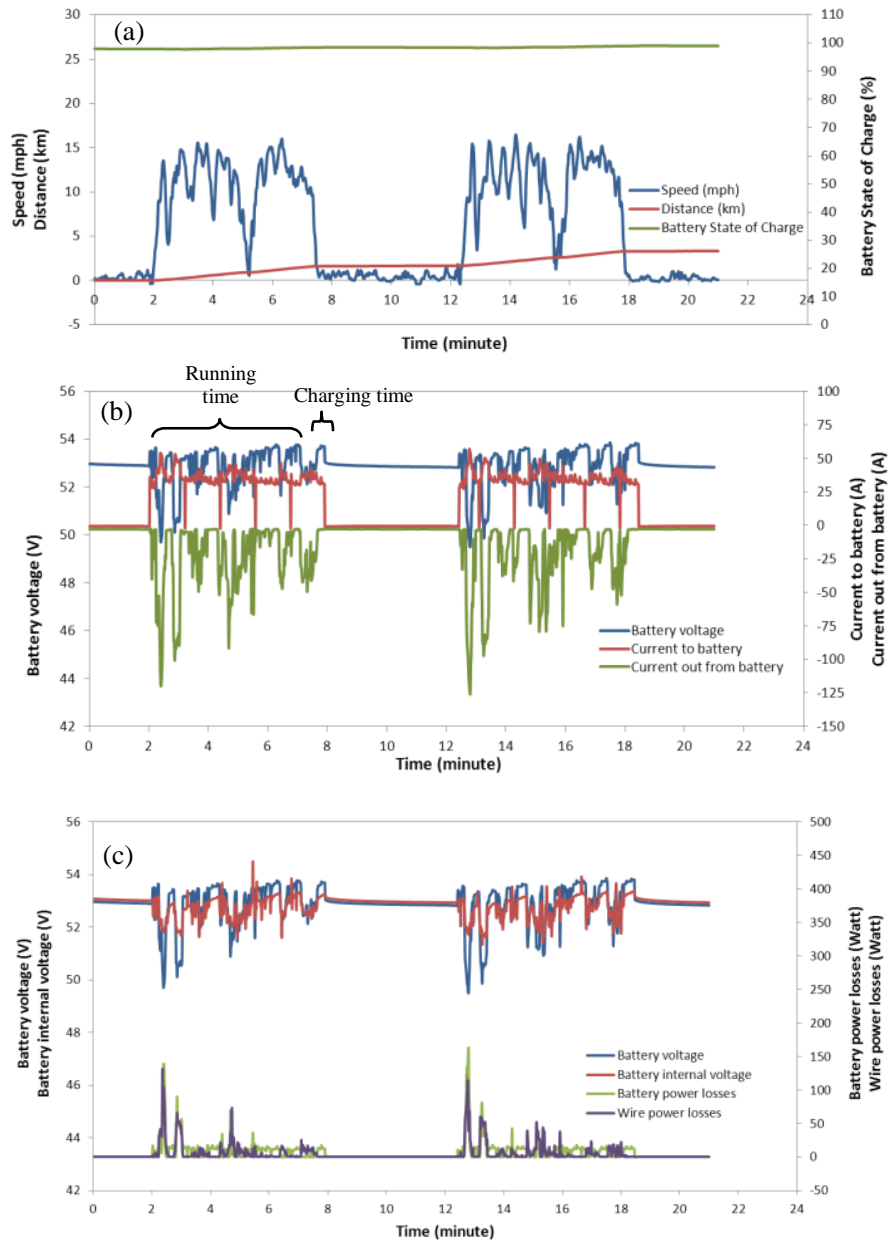

Fig. 8. (a) GPS result and battery state of charge (SOC); (b) battery condition; and (c) Losses and battery internal voltage for run on battery, Ballard, and Horizon fuel cell without passenger

The battery power losses in this experiment based on Fig. 8(c) were much less than run on battery and run on battery and Ballard. The reason for this is because during running, the current from fuel cell could directly flow to the motor controller without through the battery. The fuel cells are the main propulsion system. When the motor needed power lower than fuel cell power, all the power came from the fuel cells itself, while the excess power of it went into the battery (charge the battery). When the motor needed power higher than the fuel cell power, the extra powers were come from the battery [13]. With this system, it reduced charge-discharge losses. It's different from run on battery and run on battery and Ballard that used the fuel cells when the car stopped for charging, thus all the power went to the battery for charging.

\subsection{Run on Battery, Ballard, and Horizon Fuel Cell with Passenger}

The weight of passenger is $70 \mathrm{~kg}$. The result is shown in Fig. 9(a)-(c). The charging time for run with passenger is longer than without passenger. This happened because with the addition of passenger, the motor needed higher power than without passenger. For that condition, the motor took more power from the battery as the extra power. This made the capacity of battery lower, thus need longer charging time. Taking more power from the battery and longer charging time 
made the charge-discharge losses higher (Fig. 9(c)). Therefore, the battery power losses for run with passenger were higher than without passenger.
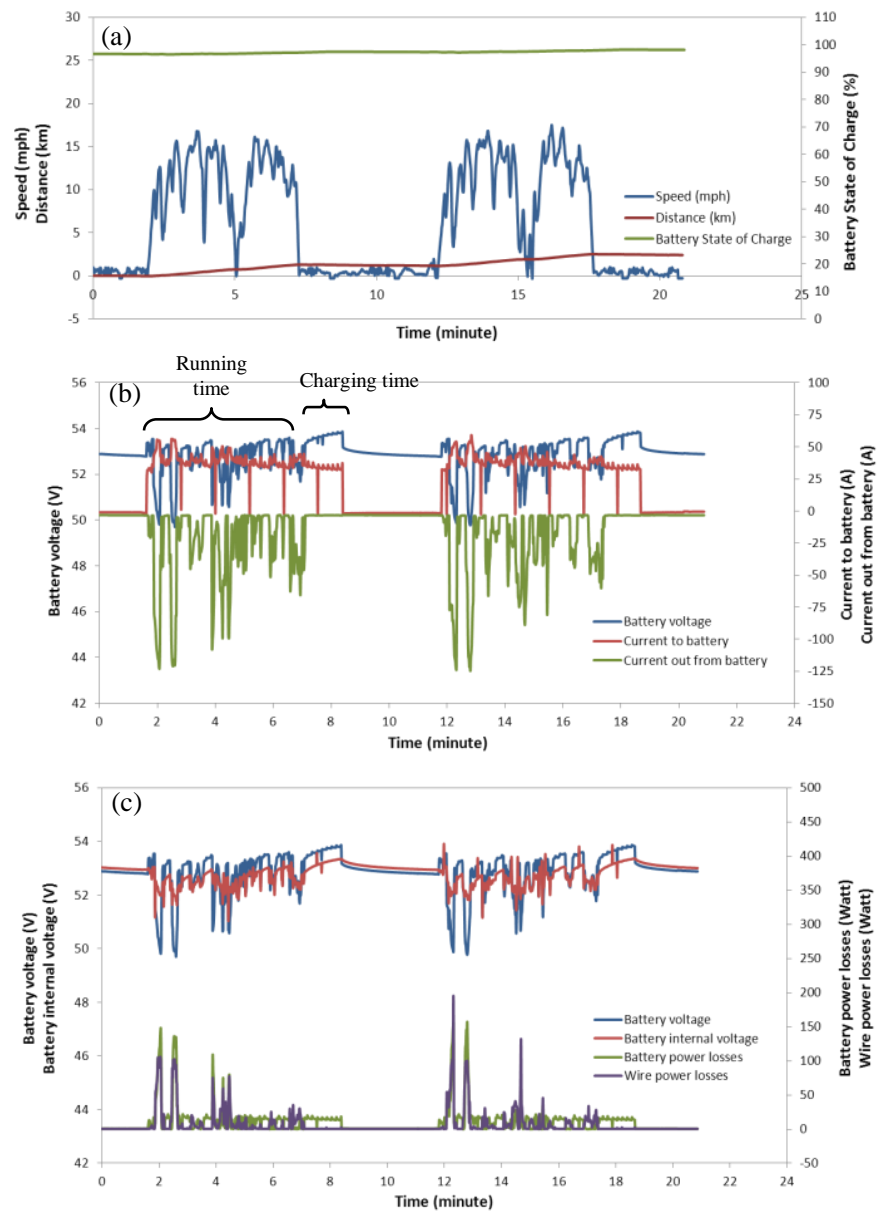

Fig. 9. (a) GPS result and battery state of charge (SOC); (b) battery condition; and (c) Losses and battery internal voltage for run on battery, Ballard, and Horizon fuel cell with passenger

Based on Table 2, the state of charge for bottom two were higher than up two. This high possibility because the mistake of Squirrel data logger. The Squirrel data logger was not fast enough to measure voltage and current when the charging and discharging were at the same time. In another word, the SOC data for bottom two were less accurate than up two. The SOC change must be not very big as the bottom two because the start voltage and end voltage of the batteries for run on battery Ballard, and Horizon with and without passenger were really close. Fig. 10 shows the mistake that Squirrel data logger can do. SOC change negative mean the batteries end charge are less than start charge and positive mean more than start charge.

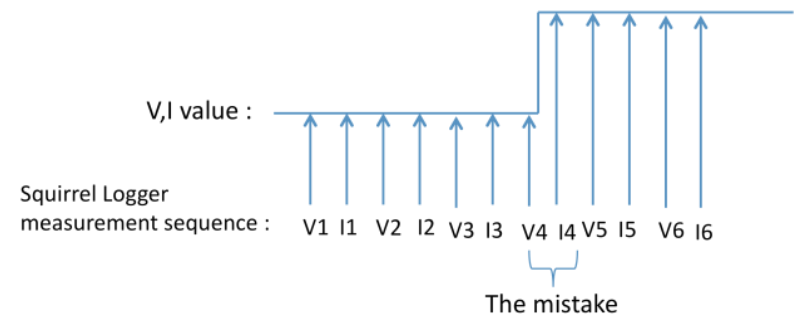

Fig. 10. Illustration the mistake of Squirrel logger

\subsection{Energy Consumption}

The summary of energy consumption of these experiments is shown in Table 3. From Table 3, it can be seen that the lowest energy efficiency was run on battery and Ballard fuel cell. To analyze how the energy was used, the energy consumption breakdown was made (Fig. 11(a)-(d)). Because of SOC change was positive for run on (Table 2), thus this over energy can be put as the battery energy consumption. The pie diagrams of energy consumption breakdown give the reason why run on battery and Ballard fuel cell was less efficient than run on battery.

Table 3. Summary of energy consumption for five runs

\begin{tabular}{lccc}
\hline Run Type & $\begin{array}{c}\text { Hydrogen } \\
\text { consumption } \\
(\mathrm{Kg})\end{array}$ & $\begin{array}{c}\text { Energy } \\
\text { consumption (MJ) }\end{array}$ & $\begin{array}{c}\text { Average energy } \\
\text { efficiency } \\
(\mathrm{km} / \mathrm{MJ})\end{array}$ \\
\hline Battery & 0.066 & 7.946 & 1.072 \\
Battery and Ballard FC & 0.070 & 8.378 & 1.010 \\
$\begin{array}{l}\text { Battery, Ballard \& } \\
\text { Horizon FC }\end{array}$ & 0.065 & 7.826 & 1.100 \\
With passenger & 0.067 & 8.011 & 1.070 \\
\hline
\end{tabular}

Run on battery and Ballard consumed more energy for the operation of Ballard (22.12\%) than run on battery $(9.08 \%)$. During the running time of run on battery and Ballard fuel cell, the duty of the Ballard fuel cell was to give the power to the $12 \mathrm{~V}$ lead acid battery and supplied the power to the $\mathrm{LiFePO}_{4}$ battery when motor controller needed high power. The $12 \mathrm{~V}$ battery was fast to be full filled by Ballard fuel cell due to auxiliaries and fuel cell controllers just took small amount of energy from the battery. Ballard fuel cell, based on Fig. 7(b), only gave small amount of power to the $\mathrm{LiFePO}_{4}$ battery. The rest of the power from Ballard fuel cell was used for operating the Ballard fuel cell. This energy operation was used for fan, air pump, and Ballard controller. During charging time, the duty of the Ballard fuel cell was only to give the power to the $12 \mathrm{~V}$ lead acid battery. For running on battery, Ballard fuel cell only was turned on during charging time (after 1 cycle). For running on battery and Ballard fuel cell, Ballard fuel cell was turned on during running and charging time. The charging time of both run were almost same (Fig. 7(b) and 8(b)) due to Ballard just gave small amount of power to the $\mathrm{LiFePO}_{4}$. These conditions made run on battery and Ballard fuel cell was less efficient than run on battery.

The highest energy efficiency was run on battery, Ballard, and Horizon fuel cell $(1.10 \mathrm{~km} / \mathrm{MJ})$. This is because the power from fuel cells could directly flow to the motor controller without through the batteries thus it reduced charge-discharge losses. In addition, the use of the Ballard fuel cell in that run was also more effective than run on battery and Ballard fuel cell because the Horizon fuel cell almost fulfill the energy required of the motor thus reduce the charging time. Reducing the charging time also reduced the operating time of the Ballard fuel cell. Ballard needed 200Watt and Horizon needed 80Watt for energy operation. 
(a)

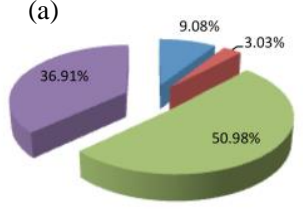

(b)
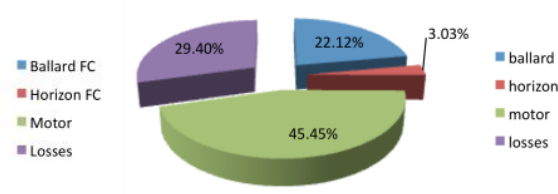

(c)

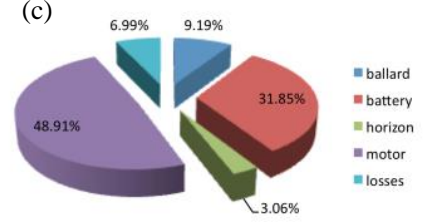

(d)

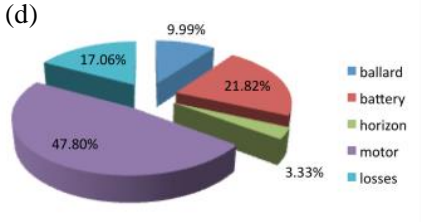

Fig. 11. Energy consumption breakdown for: (a) run on battery; (b) run on battery and Ballard fuel cell;(c) run on battery, Ballard, and Horizon fuel cell without passenger; and (d) with passenger

In contrast, the Ballard just gave small energy to the $54 \mathrm{~V}$ $\mathrm{LiFePO}_{4}$ batteries. With addition of a passenger, it consumed more hydrogen because the addition weight made the motor needed a higher power to drive the car. This concept can be related to Newton's second law, which state that the force is proportional to the mass [14]. Because it needed more power than without passenger (Fig. 11(c)-(d)), run with passenger had more power losses, particularly for battery power losses, which is shown by Fig. 11(d). The battery power losses for run with passenger were higher than without passenger because it took more power from the batteries thus increased charge-discharge losses.

The energy efficiency of this research (run on battery, Ballard and Horizon fuel cell) that used the upgraded Microcab-H4 was more efficient than original Microcab-H4 that was tested by Kendall et al [3]. That means the upgrading concept of Microcab-H4 that had been done by Shang [2] was successful and could increase the energy efficiency up to $55 \%$. Shang [2] upgraded the original of Microcab-H4 with changed lead acid battery to lithium battery which has higher energy density, changed motor to the more efficiency motor, and did not use DC-DC converter for Horizon fuel cell which could reduce the DC-DC converter losses. The result of this research also had more energy efficiency than Shang [2] that used same car but different drive cycle (ECE 15). This is because ECE 15 drive cycle has a higher average speed (18.7 $\mathrm{km} / \mathrm{h})$ than academic drive cycle $(16 \mathrm{~km} / \mathrm{h})$. The higher average speed, the more energy was needed. The summary of energy efficiency of this research and previous research is shown in Table 4.

Table 4. Comparison of energy efficiency

\begin{tabular}{lllc}
\hline \multicolumn{1}{c}{ Research } & Car type & Drive cycle & $\begin{array}{c}\text { Energy efficiency } \\
(\mathrm{km} / \mathrm{MJ})\end{array}$ \\
\hline $\begin{array}{l}\text { Kendall et al } \\
{[3]}\end{array}$ & Original & Academic drive & 0.71 \\
Microcab-H4 & $\begin{array}{l}\text { cycle } \\
\text { This research }\end{array}$ & $\begin{array}{l}\text { Upgraded } \\
\text { Microcab-H4 }\end{array}$ & $\begin{array}{l}\text { Academic drive } \\
\text { cycle }\end{array}$ \\
\hline
\end{tabular}

\section{Conclusion}

This research was done to get the energy efficiency and measure the performance of the Upgraded Microcab-H4. There were four tests run in this research: run on battery, run on battery and Ballard fuel cell, run on battery, Ballard and Horizon fuel cell, and run with passenger. The state of charge of the battery for run on battery and run on battery and Ballard decreased during running. However, state of charge of the battery for run on battery, Ballard, and Horizon fuel cell with and without passenger were stable during running. By turning on both fuel cells during running, the power from fuel cells could directly flow to the motor controller without through the batteries. This condition reduced the battery power losses.

Based on three experiments that had been done, the Ballard fuel cell was not efficient because it just gave a small amount of energy to the motor and the most of the energy that Ballard produced was for its operation. Run on battery and Ballard fuel cell was the lowest energy efficiency. The highest energy efficiency was run on battery, Ballard, and Horizon fuel cell. With addition of 1 passenger, the energy efficiency was less than without passenger. The energy efficiency of this research was higher than the original car [3]. The energy efficiency of this research was also higher than the test [2] with the same car but use ECE 15 drive cycle.

For future research, it is highly recommended to do run on battery and Horizon fuel cell because Ballard fuel cell is not efficient. Because some mistakes that had been done by Squirrel data logger, future research has to use higher accuracy and faster data logger. Many noises were gotten from GPS, thus better GPS is needed for future research.

\section{References}

1. I. Staffel, Results from the Microcab fuel cell vehicle demonstration at the University of Birmingham, Int. J. Electric and Hybrid Vehicles 3(1) (2012) 62-81.

2. J. Shang, The role of hydrogen and fuel cell for ultra low carbon vehicle, PhD Thesis, University of Birmingham, UK, 2012.

3. K. Kendall, B. G. Pollet, A. Dhir, I. Staffel, B. Millington and J. Jostins, Hydrogen fuel cell hybrid vehicles (HFCHV) for Birmingham campus, J. Power Sources 196 (2009) 325-330.

4. R. M. Moore, K. H. Hauer, S. Ramaswamy and J. M. Cunningham, Energy utilization and efficiency analysis for hydrogen fuel cell vehicles, J. Power Sources 159 (2006) 1214-1230.

5. Fuelcell Store, 300W Fuel Cell STack User Manual, Horizon Fuel Cell Technology, 2013.

6. Ballard Nexa ${ }^{\mathrm{TM}}$, Nexa $^{T M}$ Power Module User's Manual, Ballard Power System Inc, 2003.

7. Calb, CA180FI, 2011 [cited 2015 August 11]. Available from: http://en.calb.cn/product/show/?id-629.

8. J. Zheng, J. Ye, J. Yang, P. Tang, L. Zhao and M. Kern, An optimized control method for a high utilization ratio and fast filling speed in hydrogen refueling stations, Int. J. Hydrogen Energy 35 (2009) 30113017.

9. W. Chang, The state of charge estimating methods for battery: A review, ISRN Appl Math 2013 (2013) 1-7.

10. R. Nave, Static friction [internet]. 2014 [cited 2015 August 12]. Available from: http://hyperphysics.phy-astr.gsu.edu/hbase/frict2.html 
11. U. S. Kim, J. Yi, C. B. Shin, T. Han and S. Park, Modeling the thermal behavior of a lithium-ion battery during charge, J. Power Sources 196 (2011) 5115-5121.

12. M. Takahashi, S. Tobishima, K. Takei and Y. Sakura, Reaction behavior of $\mathrm{LiFePO}_{4}$ as a cathode material for rechargeable lithium batteries, Solid State Ionics 148 (2002) 283-289.

13. R. Cipollone, D. D. Battista, M. Marchionni and C. Villante, Model based design and optimization of a fuel cell electric vehicle, Energy Procedia 4 (2014) 71-80.

14. D. C. Giancoli. Physics for Scientist and Engineers with Modern Physics and Mastering Physics. $4^{\text {th }}$ Ed. Boston, MA: Addison-Wesley, 2008 